\title{
Simultaneous determination of 5 diuretic drugs using an HPLC method by quantitative analysis of multiple components by a single marker
}

\section{Fuchao Chen}

Hubei University of Medicine

\section{Baoxia Fang}

Hubei University of Medicine

Peng Li ( $\nabla$ dfyylp@163.com )

Hubei University of Medicine

Sicen Wang

Xi'an Jiaotong University

\section{Research Article}

Keywords: Diuretic drug, Multi-components detection with a single marker, HPLC, Method development

Posted Date: April 8th, 2021

DOl: https://doi.org/10.21203/rs.3.rs-397940/v1

License: (c) (i) This work is licensed under a Creative Commons Attribution 4.0 International License. Read Full License 
Simultaneous determination of 5 diuretic drugs using an HPLC method by quantitative analysis of multiple components by a single marker

Fuchao Chen ${ }^{1}$, Baoxia Fang ${ }^{1}$, Peng $\mathrm{Li}^{1 *}$, and Sicen Wang ${ }^{2 *}$

1 Sinopharm Dongfeng General Hospital, Hubei University of Medicine, Shiyan, Hubei, 442008, P.R. China. 2 School of Pharmacy, Xi'an Jiaotong University, Xi'an, 710061, Shanxi, PR China.

Fu-chao Chen and Baoxia Fang contributed equally to this work and should be considered as equal first authors.

Correspondence to: Peng Li, E-mail: dfyylp@163.com. Sinopharm Dongfeng General Hospital, Hubei University of Medicine, Shiyan, Hubei, 442008, P.R. China.Sicen Wang, E- mail: wangsc@mail.xjtu.edu.cn. School of Pharmacy, Xi'an Jiaotong University, Xi'an, 710061, Shanxi, PR China. 


\begin{abstract}
:
Background: Loop diuretics are commonly used in clinical practice to manage high fluid loads and to control fluid balance. In this paper, a novel quantitative analysis method for multiple components with a single marker (QAMS) was developed for the simultaneous determination of 5 diuretic drugs furosemide, torasemide, azosemide, etacrynic acid, and bumetanide, by HPLC. Qualitative analysis was performed using relative retention time and ultraviolet (UV) spectral similarity as the double indicator. The QAMS method was conducted with etacrynic acid as an internal reference substance. The quantities of the other four diuretics were calculated by using the relative correction factors for etacrynic acid. The quantities of the 5 diuretic drugs were also determined by the external standard method (ESM). Chromatographic separation was achieved on a Shimadzu HC-C 18 column $(150 \mathrm{~mm} \times 4.6 \mathrm{~mm}, 5 \mu \mathrm{m})$ using $50 \mathrm{mM}$ potassium dihydrogen phosphate ( $\mathrm{pH}$ adjusted to 4.0 with phosphoric acid) with acetonitrile $(64: 36, \mathrm{v} / \mathrm{v})$ as the mobile phase at a flow rate of $1.0 \mathrm{~mL} / \mathrm{min}$ and a column temperature of $30^{\circ} \mathrm{C}$.
\end{abstract}

Results: Under these conditions, the 5 diuretic drugs were well separated, showing linear relationships within certain ranges. The quantitative results showed that there was no significant difference between the QAMS and ESM methods.

Conclusions: Overall, the HPLC-QAMS analytical scheme established in this study is a simple, efficient, economical, and accurate method for the quantitative evaluation of 5 diuretic drugs.

Keywords: Diuretic drug; Multi-components detection with a single marker; HPLC; Method development 


\section{Introduction}

Loop diuretics (LDs) are a kind of drug prescribed widely in clinical practices to manage the high fluid load and to control fluid balance [1]. The pharmacologic action of LDs, blocks the $\mathrm{Na}^{+}-\mathrm{K}^{+}-2 \mathrm{Cl}^{-}$cotransporter, which transfusions from the tubular lumen into tubular cells. They inhibit $\mathrm{Na}^{+}$and $\mathrm{Cl}^{-}$reabsorption in the thick ascending limb of the loop of Henle and cause increased secretion of water, $\mathrm{K}^{+}, \mathrm{Na}^{+}$, and $\mathrm{Cl}^{-}$[2]. Furosemide, torasemide, azosemide, bumetanide, and etacrynic acid are examples of this class of diuretics [3].

Furosemide (Fig 1a), a 5-sulfamoylbenzoic acid derivative LD, has been the most widely prescribed with regard to administration via continuous infusion, and the chemical name is 5-(aminosulfonyl)-4-chloro-2-([2-furanylmethyl]amino)benzoic acid [4]. Torasemide (Fig 1b), a nonacidic LD, has a long half-life, long time of action, and higher bioavailability than the other LDs, and its chemical name is 1-[4-(3-methylphenyl)aminopyridine-3-based] sulfonyl-3-isopropylurea Azosemide (Fig 1c), [2-chloro-5-(1H-tetrazole-5-yl)-N4-(2-thenyl)sulfanilamide], is a sulfonamide LD, that is used clinically in the treatment of oedema of various geneses and hypertension [6]. Bumetanide (Fig 1d), a 5-sulfamoylbenzoic acid derivative LD, has the chemical name 3-(aminosulfonyl)-5-(butylamino)-4- phenoxybenzoic acid [7]. Etacrynic acid (Fig 1e), [2,3-dichloro-4-(2-methyl- enebutyryl)phenoxy)-acetic acid], is chemically different from all other known diuretic agents, and is now mainly used for patients with severe sulfonamide allergies that prohibit the use of other LDs [8].

Currently, several analytical methods have been reported by HPLC for the quantification of furosemide, torasemide, azosemide, bumetanide, or etacrynic acid either alone or in combination with other drugs, both in their prescribed forms and in biological fluids [9-21]. The abovementioned methods, however, have not been employed for the simultaneous quantification of the five LDs in any pharmaceutical formulation. The QAMS method is able to simultaneously determine the concentrations of multiple components by a single reference standard, which greatly reduces the cost and reduction of the analysis time of the experiment [22-29]. Thus, the present study developed a rapid HPLC-QAMS method for the determination of the five LDs. The developed QAMS method was evaluated by comparing the calculated results with an external standard method (ESM) method. This method was 
then successfully applied for the quality evaluation of formulas of the five LDs in hospitals.

\section{Experimental}

\section{Materials and reagents}

Five reference substances (furosemide, torasemide, azosemide, bumetanide, and etacrynic acid) were obtained from the National Institutes for Food and Drug Control (Beijing, China). The purity of each of the five reference substances was higher than 99\%. Chromatographic grade methanol and acetonitrile were purchased from Kemiou Chemical Reagent Co., Ltd. (Tianjin, China). AR grade of potassium dihydrogen phosphate $\left(\mathrm{KH}_{2} \mathrm{PO}_{4}\right)$, triethylamine, and phosphoric acid were obtained from Sinopharm Chemical, Shanghai, China. Pharmaceutical formulations containing furosemide, torasemide, azosemide, bumetanide, or etacrynic acid were obtained commercially.

\section{Apparatus and analytical conditions.}

Chromatographic separations were achieved on an Agilent HPLC 1260 system equipped with a diode array detector (G4212B), autosampler (G1329B), quaternary pump (G1311C), and column oven (G1316A). A digital workstation with ChemStation software Version C.01.10 served as both a controller and data manager for the overall system.A Shimadzu HC-C ${ }_{18}$ column $(150 \mathrm{~mm} \times 4.6 \mathrm{~mm}, 5 \mu \mathrm{m})$ was applied during the study under the following analytical conditions: the mobile phase was composed of acetonitrile with $0.05 \mathrm{~mol} / \mathrm{L} \mathrm{KH}_{2} \mathrm{PO}_{4}$ ( $\mathrm{pH}$ adjusted to 4.0 using diluted phosphoric acid) (36: 64, v/v) at detection wavelengths of $260 \mathrm{~nm}$ and $278 \mathrm{~nm}$, at a flow rate of $1.0 \mathrm{~mL} / \mathrm{min}$. The column temperature was retained at $30^{\circ} \mathrm{C}$, and a sample volume of $20 \mu \mathrm{L}$ was injected by an automatic sampler.

\section{Laboratory prepared mixture standard solution.}

Furosemide, torasemide, azosemide, bumetanide, and etacrynic acid references were weighed precisely to $25.0 \mathrm{mg}$ each, and then the compounds were dissolved in the mobile phase in a $50 \mathrm{~mL}$ volumetric flasks. These stock standard solutions were stored at $4{ }^{\circ} \mathrm{C}$ and warmed to room temperature before use. Mixed working solutions of the five LDs were prepared, and the mobile phase was added to form a mixed 
reference solution with a concentration of approximately $50 \mu \mathrm{g} / \mathrm{mL}$ of the reference substance.

\section{Method Validation}

The method was validated according to the International Conference of Harmonization ( $\mathrm{ICH})$ guidelines [30]. The following parameters were investigated: linearity, precision, stability, accuracy, limit of detection and robustness.

\section{Linearity and range}

The linearity and range of the method were evaluated with the standard solution of the five LDs at six different concentrations. The concentrations ranged from 2.5 to $150.0 \mathrm{ug} / \mathrm{ml}$ for the five LDs, respectively. The mixed test working standard solutions were prepared by appropriate dilution of the stock solutions with mobile phase to the required concentrations for plotting the calibration curves. A $20 \mu \mathrm{L}$ aliquot of each working solution was injected in triplicate into the chromatographic system $(n=3)$. The standard curves of the five LDs were constructed from the different concentrations of the mixed solution. Chromatograms were recorded, and the standard calibration curve was generated with peak area as the $\mathrm{Y}$-axis (Y) and the concentration $(\mu \mathrm{g} / \mathrm{mL})$ of each standard solution as the $\mathrm{X}$-axis $(\mathrm{X})$.

\section{Precision}

The mixed standard solution at the same concentration was continuously injected six times on the same day or on different days according to the chromatographic conditions described in Section analytical conditions. The relative standard deviation (RSD) values were evaluated by the chromatographic peak area of the five LDs.

\section{Stability}

The same mixed working standard solutions were injected into the HPLC at $0 \mathrm{~h}, 2 \mathrm{~h}$, $4 \mathrm{~h}, 6 \mathrm{~h}$ and $8 \mathrm{~h}$ with the same mobile phase. The RSDs of the five peaks areas were determined.

\section{Recovery}

The accuracy of the assay method was calculated in triplicate by adding known amounts of the five LD reference substances to commercial sample solutions. Each 
solution was prepared at three concentrations (i.e., 40, 50, and $60 \mu \mathrm{g} / \mathrm{mL}$ ), and each solution was injected into HPLC in triplicate. Then, the peak areas were recorded, and the average recovery, and RSD \% of each LD were calculated.

\section{Robustness}

The robustness study was conducted by examining the samples on three different HPLC instruments: a Dionex U3000, an Agilent 1260 series, and a Shimadzu LC-20A. Three different models of chromatographic columns were used, including an Agilent Zorbax Extend $\mathrm{C}_{18}$, Shimadzu HC-C ${ }_{18}$ column, and Kromasil $\mathrm{C}_{18}(150 \mathrm{~mm} \times 4.6 \mathrm{~mm}, 5$ um). The samples were determined to have various $\mathrm{pH}$ values $(3.8,4.0,4.2)$, flow rates of the mobile phase $(0.98 \mathrm{~mL} / \mathrm{min}, 1.0 \mathrm{~mL} / \mathrm{min}$, and $1.02 \mathrm{~mL} / \mathrm{min})$ and column temperatures $\left(29^{\circ} \mathrm{C}, 30^{\circ} \mathrm{C}\right.$, and $\left.31^{\circ} \mathrm{C}\right)$. The separation degree and $\% \mathrm{RSD}$ of the five LDs were investigated.

\section{Qualitative investigation.}

\section{UV spectral similarity.}

The mixed standard solutions of five LDs were injected into HPLC under the above analytical conditions. The chromatogram maps and UV spectra were recorded, and the similarity of the original and first-order spectra of the five LDs was analysed by the ChemStation software Version C.01.10.

\section{Relative retention time.}

Under the analytical conditions described in sections analytical conditions and robustness, the same standard solutions of the five LD mixtures were tested and peak retention times were recorded to determine the relative retention time (RRT). The RRT is calculated by the following formulae [1]:

$$
\mathrm{RRT}=\left(\mathrm{t}_{\mathrm{A}}-\mathrm{t}_{0}\right) /\left(\mathrm{t}_{\mathrm{R}}-\mathrm{t}_{0}\right)
$$

where $t_{0}, t_{R}$ and $t_{A}$ represent the retention times of urine pyrimidine, etacrynic acid, and analyte, respectively.

\section{Quantitative Analysis of Multiple Components by a Single Marker (QAMS)}

The application of the QAMS method in the quality control of the five diuretic drugs was based on the relative correction factor (RCF) of each component, which is 
proportional to the detection signal in a certain concentration range. In this study, we selected etacrynic acid as the internal standard, and used equation (2) to calculate the RCF of the other diuretics.

$$
\mathrm{RCF}=\frac{\mathrm{RCF}_{s}}{\mathrm{RCF}_{i}}=\frac{A_{s} / C_{s}}{A_{i} / C_{i}}
$$

where $A_{s}$ is the peak area of the internal standard (etacrynic acid), $C_{g}$ is the concentration of the internal standard (etacrynic acid), $A_{\tilde{i}}$ is the peak area of other investigated components $\mathrm{i}$, and $C_{\tilde{i}}$ is the concentration of other investigated component $i$ in the sample solution.

From the equation (2), we can derive the equation (3)

$$
C i=\mathrm{RCF} \times C_{s} \times \frac{A_{i}}{A_{s}}
$$

We can use equation (3) to calculate the concentration of each component of the sample solution. Additionally, the effects of the different HPLC systems, the $\mathrm{pH}$ of the mobile phase, the gradient elution scheme, the flow rate, the injection volume and the column temperature given in section robustness for the RCF were investigated.

Analysis of the five LDs in commercial injections

To determine the content of furosemide, bumetanide, and torasemide, commercially available injections of the 3 diuretics were prepared with the mobile phase. To determine the content of azosemide and etacrynic acid in conventional tablets, ten tablets were weighed, and disintegrated by shaking for $1 \mathrm{~min}$ with $10 \mathrm{~mL}$ water in a $100 \mathrm{~mL}$ volumetric flask. $40 \mathrm{~mL}$ acetonitrile was added. The samples were ultrasonically treated for $20 \mathrm{~min}$, and diluted with purified water to a volume of 100 $\mathrm{mL}$. Then, the samples of the 5 diuretics were injected into the HPLC according to the above described analytical method.

\section{Results and Discussion}

\section{Optimization of analytical conditions}

To establish a method for the simultaneous determination of five LDs by HPLC with DAD detection, solutions of methanol/water, methanol/water containing triethylamine or phosphoric acid, acetonitrile/water, and acetonitrile/water containing 
phosphoric acid or triethylamine were first used to separate the compounds, but the selectivity between these five LDs was not optimal. Then, we chose a $0.05 \mathrm{~mol} / \mathrm{L}$ solution of potassium dihydrogen phosphate with acetonitrile, which provided a different selectivity than the other conditions and thus a better separation between the five LDs. Representative HPLC chromatograms for the simultaneous separation of the five LDs with different buffer $\mathrm{pH}$ or acetonitrile contents are shown in Fig 2 and Fig 3. The mobile phase composed of acetonitrile $-0.05 \mathrm{~mol} / \mathrm{L}$ of $\mathrm{KH}_{2} \mathrm{PO}_{4}(\mathrm{pH}$ adjusted to 4.0 using diluted phosphoric acid) $(36: 64, \mathrm{v} / \mathrm{v})$ provided a short analysis time that did not exceed 25 min while maintaining acceptable resolution between compounds.

\section{Method Validation}

The linear range, precision, stability, and recovery results are showed in Tables 1 and 2. The linear range of all five LDs was wide and showed a good linear relationship ( $r>0.999)$. As shown, the precision was measured in two parts: intraday precision (with RSD values between $0.6 \%$ and $1.8 \%$ ), and interday precision (with RSD values between $1.4 \%$ and $2.3 \%$ ), which showed that the instrument had good precision. The $\mathrm{RSD} \%$ of the peak areas for furosemide, torasemide, azosemide, bumetanide, and etacrynic acid for stability were $1.1 \%, 0.7 \%, 1.3 \%, 1.1 \%$, and $0.5 \%$, indicating that the sample solutions were stable over $8 \mathrm{~h}$. The recovery results revealed average recovery rates from $97.2 \%$ to $102.1 \% \%$ with an $\mathrm{RSD}<1.9 \%$, indicating that the method had good accuracy. All of the above results show that the established methods were effective and reliable.

\section{Qualitative investigation.}

\section{UV Spectral Similarity.}

The similarity of the UV spectra is due to the chemical structure of compounds, and different compounds have different UV absorption spectra, which can be used to characterize the LD compounds. The original and first-order spectra, illustrating the similarities of the five diuretics are shown in Table 3-4, and the vector graph of the five diuretics is shown in Fig 4, which indicates that the first-order spectra after derivation show more characteristic details than the original spectra. The similarity of the UV spectra can be used for the qualitative identification of the five diuretics, which improves the accuracy and other characterization. 


\section{Relative retention time.}

The HPLC methods used in the literature mostly use the retention time to carry out the qualitative analysis. In multicomponent qualitative analysis, heavy use of the reference substance increases the detection cost; in the detection process, the reference substance often cannot be rapidly obtained, and the retention time is affected by the instrument, brand of chromatographic column, column temperatures, and flow rates or $\mathrm{pH}$ of the mobile phase. In addition, the five LD compounds with similar chemical structures and physical properties are difficult to qualitatively investigate base on the retention time of the components. In this experiment, the RRTs were chose as a qualitative analysis index, and their robustness was investigated. The robustness results of the RRTs for the five LDs are shown in Table 5. The results showed that the RRTs were not affected by different instruments, flow velocity, mobile phase volume, $\mathrm{pH}$ value or column temperature (RSD was less than $5.0 \%$ ). In the same system, different HPLC columns gave RRTs with a RSD $>31.0 \%$, which failed to satisfy the requirements of qualitative analysis. The differences between RRTs can mainly be attributed to different manufacturers, and are associated with the properties and preparation of packing materials. To this end, we herein restricted the conditional parameters and used spectral similarity and RRT as the double indicator to qualify the qualitative analysis.

\section{Quantitative study of QAMS.}

Inspired by the HPLC-based ESM analytical method, QAMS uses a single component as the internal standard to simultaneously quantitatively measure itself and other analytes by calculating relative correction factors (RCFs). In recent decades, the QAMS method has been widely used in the evaluation of a large number of Chinese herbal medicines[22-28], drugs[29] and drug impurities [31-32]. In this study, etacrynic acid was chosen as an internal reference to calculate the RCF of the other four diuretics. To evaluate the robustness of the $\mathrm{RCF}$, the influence of the $\mathrm{pH}$ values of mobile phase, ratio and flow rates of the mobile phase, chromatographic column types, chromatographic column temperatures, and injection volumes were investigated. The RCFs of the five LDs are shown in Table 6. The results show that the RCF experiment is repeatable under different analytical conditions, which ensures that the QAMS method can be well applied to routine analysis. 


\title{
Sample Analysis
}

The quantities of the five LD samples determined by HPLC-ESM and HPLC-QAMS are shown in Table 7. Comparative analysis indicated that there was no significant difference between HPLC-ESM and HPLC-QAMS (RSD values were < $3.0 \%$ ), which shows that the above method is accurate and reliable.

\section{Conclusion.}

In this paper, a method for the simultaneous determination of five diuretic drugs by HPLC-ESM and HPLC-QAMS was developed. In the HPLC-QAMS process, etacrynic acid was used as an internal reference to calculate the relative correction factor of the other four diuretics, and the influencing factors such as different chromatographic columns, instruments, column temperatures, mobile phases and flow velocities were investigated. The above established method was successfully applied to the qualitative identification and quantitative analysis of five LDs. Because the QAMS analysis method can provide reliable results, save reference materials and shorten analysis time, it has great potential for an enhanced role in hospital-based quality control and qualitative identification and quantitative analysis of diuretics in other medicinal materials.

\begin{abstract}
Abbreviations
LDs: Loop diuretics; HPLC: high performance liquid chromatography; QAMS: quantitative analysis of multiple components with a single marker; ESM: external standard method; RSD: relative standard deviation; RCFs: relative correction factors
\end{abstract}

\section{Declarations}

\section{Ethics approval and consent to participate}

Not Applicable.

\section{Consent for publication}

Not Applicable.

\section{Availability of data and materials}

The majority of the data used to support the findings of this study are included within the article. Other data are available from the corresponding author upon request. 


\section{Competing interests}

The authors declare that there is no conflict of interests regarding the publication of this paper.

\section{Funding}

This study was financially supported by Technology Key Program of Shiyan, China (number 18Y73).

\section{Authors' contributions}

FCC and BXF provided the loop diuretics drugs and dosage forms, proposed the subject, analyze and interpret of the data, draft the article. PL and SCW designed the assay, conducted its validation, and participated in revision of the manuscript.

\section{Acknowledgements}

The authors acknowledged the support from Renmin hospital of Hubei University of Medcine.

\section{Authors' information}

\section{Affiliations}

Sinopharm Dongfeng General Hospital, Hubei University of Medicine, Shiyan, Hubei, 442008, P.R. China.

Fuchao Chen, Baoxia Fang, Peng Li

School of Pharmacy, Xi'an Jiaotong University, Xi'an, 710061, Shanxi, PR

\section{China.}

Sicen Wang

\section{References}

1. Roush GC, Kaur R, Ernst ME (2014) Diuretics: a review and update. J Cardiovasc Pharmacol Ther 19: 5-13.

2. Wile D (2012) Diuretics: a review. Ann Clin Biochem 49: 419-431.

3. Anisman SD, Erickson SB, Morden NE (2019) How to prescribe loop diuretics in oedema. BMJ 364: 1359. 
4. Ng KT, Jll Y (2018) Continuous infusion vs. intermittent bolus injection of furosemide in acute decompensated heart failure: systematic review and meta-analysis of randomised controlled trials. Anaesthesia 73: 238-247.

5. Cosín J, Díez J (2002) Torasemide in chronic heart failure: results of the TORIC study. Eur J Heart Fail 4: 507-513.

6. Lykke K, Töllner K, Erker T (2015) Structure-activity relationships of bumetanide derivatives: correlation between diuretic activity in dogs and inhibition of the human NKCC2A transporter. Brit J Pharmacol 172: 4469-4480.

7. Alisky JM, Tuttle TF (2003) Ethacrynic acid can be effective for refractory congestive heart failure and ascites. South Med J 96: 1148-1150.

8. Hampel P, Römermann K, MacAulay N (2018) Azosemide is more potent than bumetanide and various other loop diuretics to inhibit the sodium- potassiumchloride- cotransporter human variants hNKCC1A and hNKCC1B. Sci Rep 8: 9877.

9. Zhang L, Wang RL, Tian Y (2015) Determination of torasemide in human plasma and its bioequivalence study by high-performance liquid chromatography with electrospray ionization tandem mass spectrometry. J Pharm Anal 6: 95-102.

10. Stolarczyk M, Hubicka U, Krzek J (2015) Simultaneous determination of eight hypotensive drugs of various chemical groups in pharmaceutical preparations by HPLC-DAD. J AOAC Int 98: 1542-1548.

11. Subramanian V, Nagappan K, Mannemala S (2015) Optimization and validation o f a sensitive method for HPLC-PDA simultaneous determination of torasemide and $\mathrm{sp}$ ironolactone in human plasma using central composite design. Acta Chim Slov 62:63 $3-641$.

12. Legorburu M, Alonso RM, Ortiz E (2001) Quantitative determination of the loop diuretic bumetanide in urine and pharmaceuticals by high-performance liquid chroma tography with amperometric detection. J Chromatogr Sci 39:425-530.

13. Lin CW, Gonzalez P, Yuan F (2011) Cellular pharmacokinetic and pharmacodynamic analyses of ethacrynic acid: implications in topical drug delivery in the eye. Mol vis 17: 2507-2515.

14. Lukáš Zahálka, Sylva Klovrzová, Ludmila Matysová, Zdenka Šklubalová, Petr Solich (2018) Furosemide ethanol-free oral solutions for paediatric use: formulation HPLC method and stability study. Eur J Hosp Pharm 25:144-149.

15. Naguib IA, Abdelaleem EA, Emam AA, Ali NW, Abdallah FF (2018) Development and validation of HPTLC and green HPLC methods for determination 
of furosemide spironolactone and canrenone in pure forms tablets and spiked human plasma. Biomed Chromatogr 32(10): e4304.

16. Li J, Guo Z, Zhao X, Han P, Feng S (2015) Simultaneous determination of four drugs for kidney diseases in urine by high performance liquid chromatography. Se pu 33: 1210-1213.

17. Baranowska I, Płonka J (2016) Monitoring of biogenic amines and drugs of various therapeutic groups in urine samples with use of HPLC. Biomed Chromatogr 30: $652-657$.

18. Baranowska I, Markowski P, Baranowski J (2009) Development and validation of an HPLC method for the simultaneous analysis of 23 selected drugs belonging to different therapeutic groups in human urine samples. Anal Sci 1307-1313.

19. Youm I, Youan BBC (2013) Validated reverse-phase high-performance liquid chromatography for quantification of furosemide in tablets and nanoparticles. J Anal Methods Chem 2013:1-9.

20. Zhang Z, Wang D, Zhang L, Du M, Chen G (2008) Determination of diuretics in human urine by hollow fiber-based liquid-liquid-liquid microextraction coupled to high performance liquid chromatography. Analyst 133:1187-1194.

21. Chen Y, Liu Y (2011) Analytical methods for the determination of anti-diuretic peptides in biological samples: challenges and perspectives. Curr Anal Chem 7: 117129.

22. Huan Y, Jie Z, Shang XY, et al. (2018) Multi-component analysis of Ilex Kudingcha C. J. Tseng by a single marker quantification method and chemometric discrimination of HPLC fingerprints. Molecules 23: 854

23. Li Y, Zhang Y, Zhang Z, Hu Y, Cui X, Xiong Y (2019) Quality evaluation of Gastrodia Elata Tubers based on HPLC fingerprint analyses and quantitative analysis of multi-components by single marker. Molecules 24:1521.

24. Zhu C, Li X, Zhang B, Lin Z (2017) Quantitative analysis of multi- components by single marker-a rational method for the internal quality of Chinese herbal medicine. Integr Med Res 6:1-11.

25. Chen LH, Wu Y, Guan YM, Jin C, Zhu WF, Yang M (2018) Analysis of the high-performance liquid chromatography fingerprints and quantitative analysis of multicomponents by single marker of products of fermented cordyceps sinensis. Comp Biochem Physiol 17(3):799-803.

26. Wang S, Xu Y, Wang Y (2017) Simultaneous determination of six active 
components in Oviductus Ranae via quantitative analysis of multicomponents by single marker. J Anal Methods Chem 2017: 9194847.

27. Wang CQ, Jia XH, Zhu S, Komatsu K, Wang X, Cai SQ (2015) A systematic study on the influencing parameters and improvement of quantitative analysis of multi-component with single marker method using notoginseng as research subject. Talanta 134:587-595.

28. Chen A, Sun L, Yuan H, Wu A, Lu J, Ma S (2017) A holistic strategy for quality and safety control of traditional Chinese medicines by the "iVarious" standard system. J Pharm Anal 7(5):271-279.

29. Chen FC, He XD, Fang BX, Wang SC (2020) Simultaneous quantitative analysis of six proton-pump inhibitors with a single marker and evaluation of stability of investigated drugs in polypropylene syringes for continuous infusion use. Drug Des Dev Ther 14: 5689-5698.

30. International Conference on Harmonization (2005), Q2 (R1): Validation of analyt ical procedures: text and methodology, ICH, Geneva, Switzerland.

31. Guo Q, Liu L, Zhou ZG, Qin Y (2019) Content determination of 7 related substances in solifenacin succinate raw material by HPLC with principal component self-control with correction factor. China Pharm 30(11):1481-1486.

32. Yang QJ, Wang H, Gao YJ, Li JQ, Jiao JD, Quan QB, Chen JQ (2015) Application of substitution method of reference substance in the rapid determination of sedative drugs by HPLC. Chin J Mod Appl Pharm 32(11):1376-1381. 


\section{Figure legends}

\section{Figure 1.}

Chemical structures of furosemide (a), torasemide (b), azosemide (c), bumetanide (d) and etacrynic acid (e).

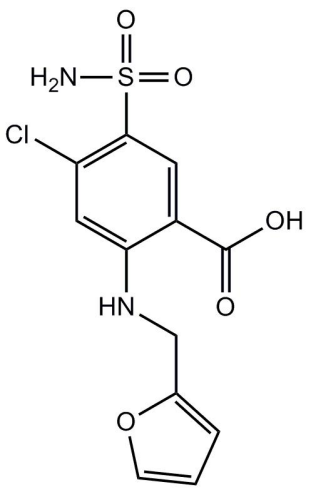

(a)

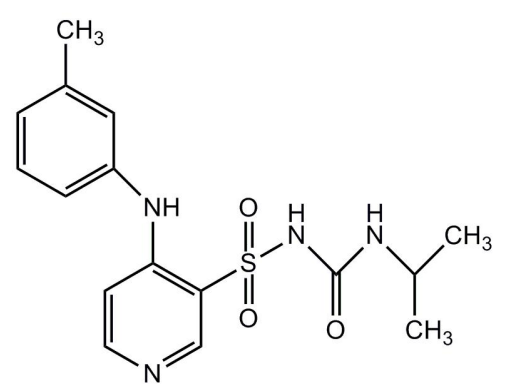

(b)

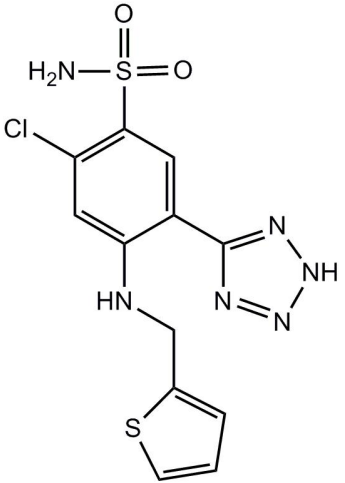

(c)<smiles>CCCCNc1cc(C(=O)O)cc(S(N)(=O)=O)c1Oc1ccccc1</smiles>

(d)

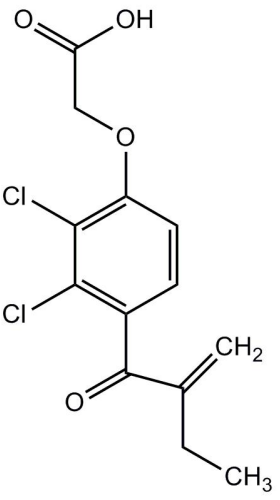

(e) 
Figure 2.

A typical chromatogram of standard drug mixture samples. Chromatographic conditions were acetonitrile- $0.05 \mathrm{~mol} \cdot \mathrm{L}^{-1}$ potassium dihydrogen phosphate $(36: 64$, $\mathrm{v} / \mathrm{v}$ ); the buffer $\mathrm{pH}$ was varied. a. $\mathrm{pH} 3.0$; b. $\mathrm{pH} 3.5$; c. $\mathrm{pH} 4.0$; d. $\mathrm{pH} 4.5$; d. $\mathrm{pH}$ 5.0.

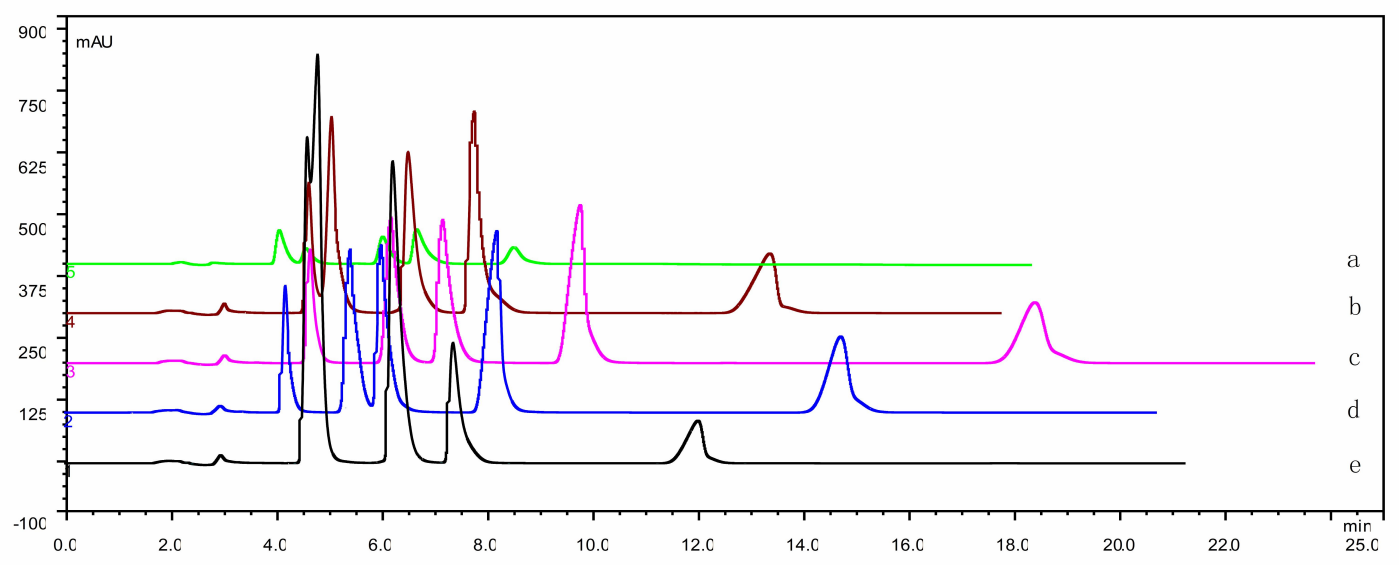


Figure 3.

A typical chromatogram of standard drug mixture samples. Chromatographic conditions were acetonitrile- $0.05 \mathrm{~mol} \cdot \mathrm{L}^{-1}$ potassium dihydrogen phosphate (phosphoric acid to adjust $\mathrm{pH}$ to 4.0); the acetonitrile content was varied. a. acetonitrile content 30 ; b. acetonitrile content 34 ; c. acetonitrile content 36; d. acetonitrile content 38; e. acetonitrile content 40 .

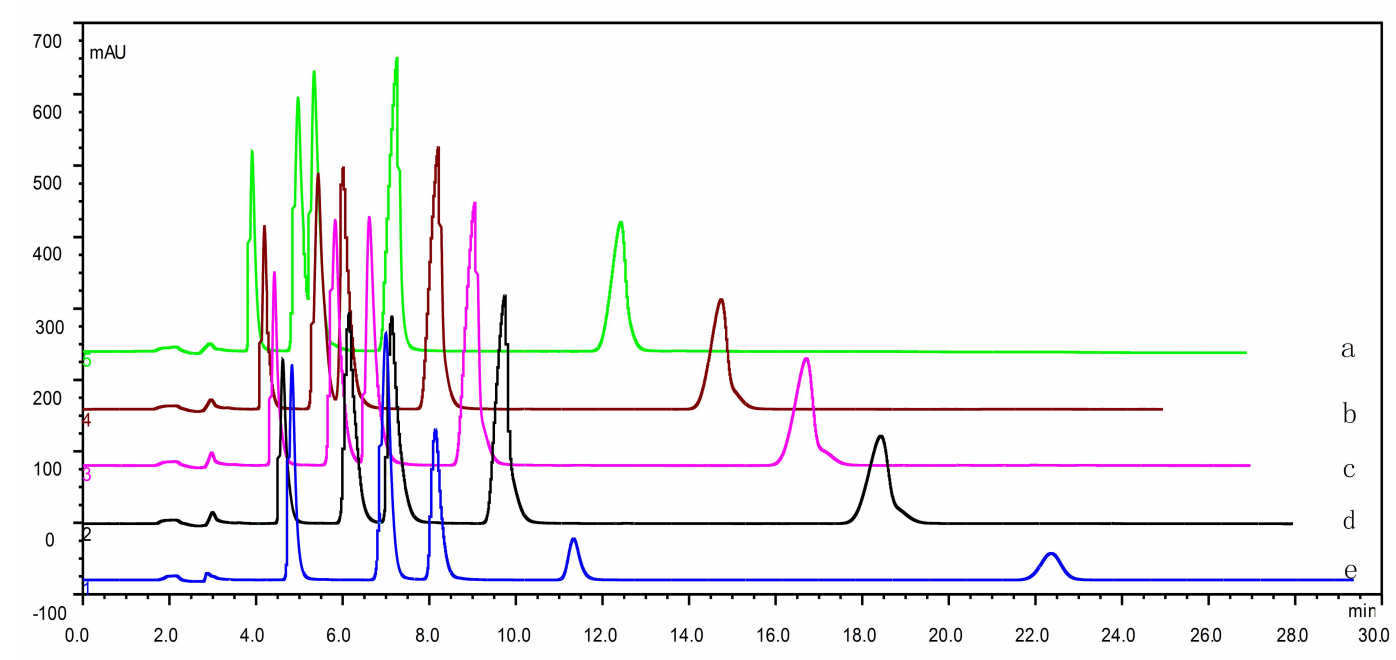




\section{Figure 4.}

UV spectra and 1st UV spectra of furosemide, torasemide, azosemide, bumetanide and etacrynic acid.

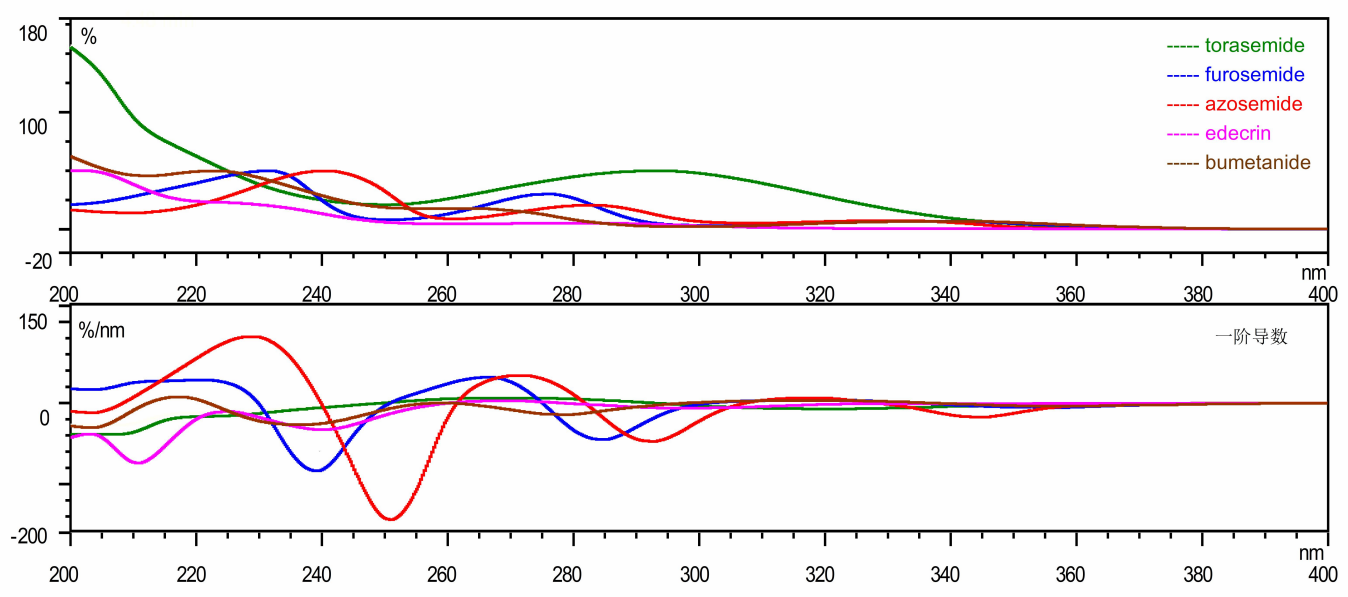


Table 1 Regression equation, correlation coefficient (r), linear range and detection limit of the five diuretic drugs

\begin{tabular}{|c|c|c|c|c|}
\hline Studied drug & Regression Equation & $\mathbf{r}$ & $\begin{array}{c}\text { (Linear Range) / } \\
\left(\boldsymbol{\mu g} \cdot \mathbf{m} \mathbf{L}^{-1}\right)\end{array}$ & $\begin{array}{c}\text { (Detection Limit) } \\
/ \mu \mathrm{g} \cdot \mathbf{m L}^{-1}\end{array}$ \\
\hline Etacrynic acid & $y=20.301 x-1.624$ & 0.9993 & $2.5-150$ & 0.25 \\
\hline Torasemide & $y=33.204 x+3.131$ & 0.9998 & $2.5-150$ & 0.08 \\
\hline Furosemide & $y=27.634 x-0.970$ & 0.9999 & $2.5-150$ & 0.05 \\
\hline Azosemide & $y=43.381 x+8.666$ & 0.9992 & $2.5-150$ & 0.13 \\
\hline Bumetanide & $y=36.124 x+1.320$ & 0.9999 & $2.5-150$ & 0.20 \\
\hline
\end{tabular}


Table 2 Recovery test of the developed HPLC analysis method

\begin{tabular}{|c|c|c|c|c|}
\hline Studied drug & $\begin{array}{c}\text { Measured } \\
\text { concentrations } \\
(\mu \mathrm{g} / \mathrm{mL})\end{array}$ & $\begin{array}{c}\text { Accuracy } \\
\%\end{array}$ & $\begin{array}{c}\text { Average } \\
\text { recovery } \\
(\%)\end{array}$ & RSD (\%) \\
\hline \multirow[t]{3}{*}{ Etacrynic acid } & 40.0 & 98.3 & & \\
\hline & 50.0 & 97.7 & 98.8 & 1.4 \\
\hline & 60.0 & 100.4 & & \\
\hline \multirow[t]{3}{*}{ Torasemide } & 40.0 & 96.7 & & \\
\hline & 50.0 & 99.1 & 98.5 & 1.6 \\
\hline & 60.0 & 99.6 & & \\
\hline \multirow[t]{3}{*}{ Furosemide } & 40.0 & 100.6 & & \\
\hline & 50.0 & 102.1 & 100.3 & 1.9 \\
\hline & 60.0 & 98.3 & & \\
\hline \multirow[t]{3}{*}{ Azosemide } & 40.0 & 97.2 & & \\
\hline & 50.0 & 98.2 & 97.9 & 0.7 \\
\hline & 60.0 & 98.4 & & \\
\hline \multirow[t]{3}{*}{ Bumetanide } & 40.0 & 97.5 & & \\
\hline & 50.0 & 100.8 & 99.3 & 1.7 \\
\hline & 60.0 & 99.6 & & \\
\hline
\end{tabular}


Table 3 UV spectra similarity of the five diuretic drugs

\begin{tabular}{lccccc}
\hline Studied drug & Torasemide & Furosemide & Azosemide & Etacrynic acid & Bumetanide \\
\hline Torasemide & 1.0000 & & & & \\
Furosemide & 0.7494 & 1.0000 & & & \\
Azosemide & 0.6574 & 0.8550 & 1.0000 & & \\
Etacrynic acid & 0.9219 & 0.7761 & 0.6553 & 1.0000 & \\
Bumetanide & 0.8965 & 0.8499 & 0.7544 & 0.9451 & 1.0000 \\
\hline
\end{tabular}

Table 4 1st UV spectra similarity of the five diuretic drugs

\begin{tabular}{lccccc}
\hline Studied drug & Torasemide & Furosemide & Azosemide & Etacrynic acid & Bumetanide \\
\hline Torasemide & 1.0000 & & & & \\
Furosemide & -0.1078 & 1.0000 & & & \\
Azosemide & -0.1712 & 0.1698 & 1.0000 & & \\
Etacrynic acid & 0.8132 & 0.0873 & -0.0475 & 1.0000 & \\
Bumetanide & 0.3288 & 0.3369 & 0.0457 & 0.1218 & 1.0000 \\
\hline
\end{tabular}


Table 5 Effects of different instruments, columns, column temperatures, flow rates, volume and pH on RRTs $(n=3)$

\begin{tabular}{|c|c|c|c|c|c|c|}
\hline & Effects Factor & Torasemide & Furosemide & Azosemide & Etacrynic acid & Bumetanide \\
\hline & Chromatographic Columns & 38.95 & 36.77 & 35.97 & - & 31.67 \\
\hline & HPLC Instruments & 1.09 & 1.24 & 3.38 & - & 2.34 \\
\hline \multirow[t]{7}{*}{$\mathrm{RSD} \%$} & Column Temperatures & 1.58 & 1.36 & 0.54 & - & 0.93 \\
\hline & Flow Volume of Mobile Phase & 2.10 & 2.11 & 0.93 & - & 1.22 \\
\hline & Flow Rate of Mobile Phase & 1.22 & 0.75 & 0.40 & - & 0.005 \\
\hline & $\mathrm{pH}$ Value of Mobile Phase & 4.87 & 3.21 & 3.99 & - & 3.71 \\
\hline & $\bar{\chi}$ & 0.31 & 0.49 & 0.63 & - & 2.11 \\
\hline & S & 0.001 & 0.001 & 0.001 & - & 0.009 \\
\hline & $\bar{\chi} \pm 3 \mathrm{~S}$ & $0.31 \pm 0.003$ & $0.49 \pm 0.004$ & $0.63 \pm 0.002$ & - & $2.11 \pm 0.028$ \\
\hline
\end{tabular}


Table 6 Relative correction factor of the five diuretic drugs

\begin{tabular}{lccc}
\hline \multicolumn{1}{c}{ Studied drug } & $\begin{array}{c}\text { Wavelength } \\
(\mathbf{n m})\end{array}$ & $\mathbf{R S D} / \%$ & $\begin{array}{c}\text { Relative Correction } \\
\text { Etacrynic acid }\end{array}$ \\
Torasemide & 277 & - & 1 \\
Furosemide & 292 & 0.18 & 0.3232 \\
Azosemide & 334 & 0.35 & 0.9024 \\
Bumetanide & 326 & 0.63 & 0.8064 \\
\hline
\end{tabular}

Table 7 Results of the comparison of the five diuretic drugs

\begin{tabular}{lcccc}
\hline & \multicolumn{2}{c}{ the QAMS Methods } & \multicolumn{2}{c}{ the ESM Methods } \\
\cline { 2 - 5 } Studied drug & Accuracy & RSD & Accuracy & RSD \\
& $(\mathbf{\%})$ & $\mathbf{( \% )}$ & $\mathbf{( \% )}$ & $\mathbf{( \% )}$ \\
\hline Etacrynic acid tablet & 95.1 & 2.1 & 96.2 & 1.9 \\
Torasemide injection & 97.4 & 1.3 & 96.8 & 1.4 \\
Furosemide injection & 103.2 & 0.7 & 102.9 & 1.0 \\
Azosemide tablet & 98.5 & 1.8 & 99.1 & 2.2 \\
Bumetanide injection & 102.4 & 1.6 & 101.6 & 1.4 \\
\hline
\end{tabular}


Figures

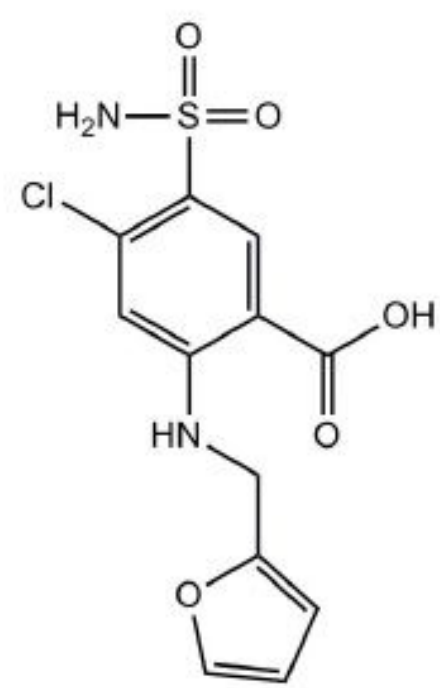

(a)<smiles>Cc1cccc(Nc2ccncc2S(=O)(=O)NC(=O)NC(C)C)c1</smiles>

(b)

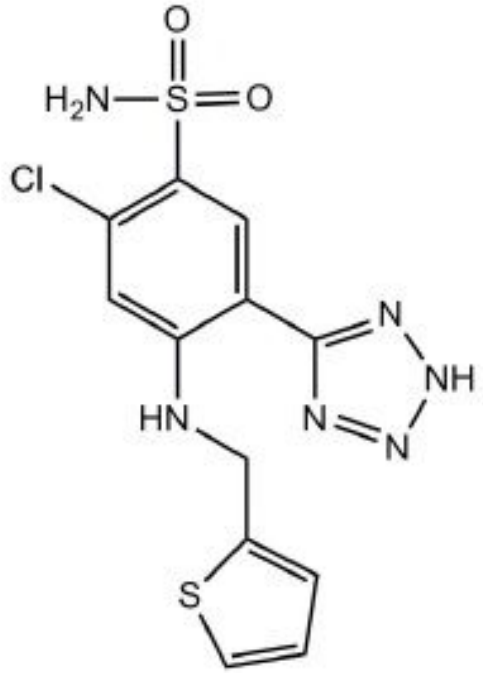

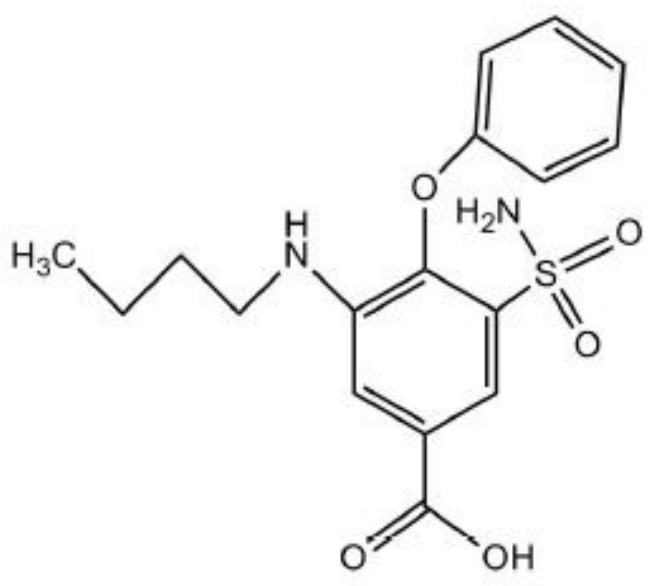

(d)

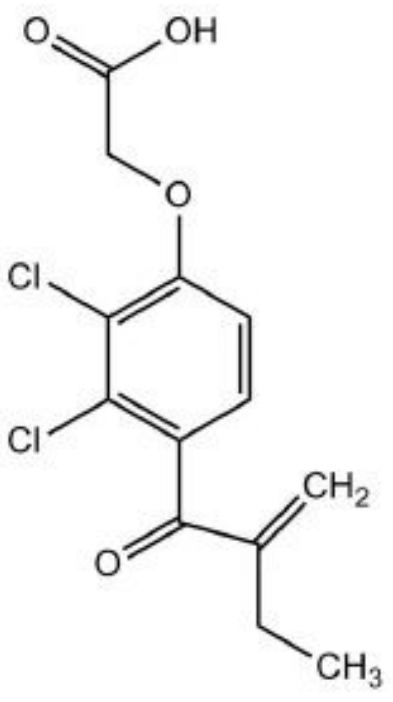

(e)

\section{Figure 1}

Chemical structures of furosemide (a), torasemide (b), azosemide (c), bumetanide (d) and etacrynic acid (e). 


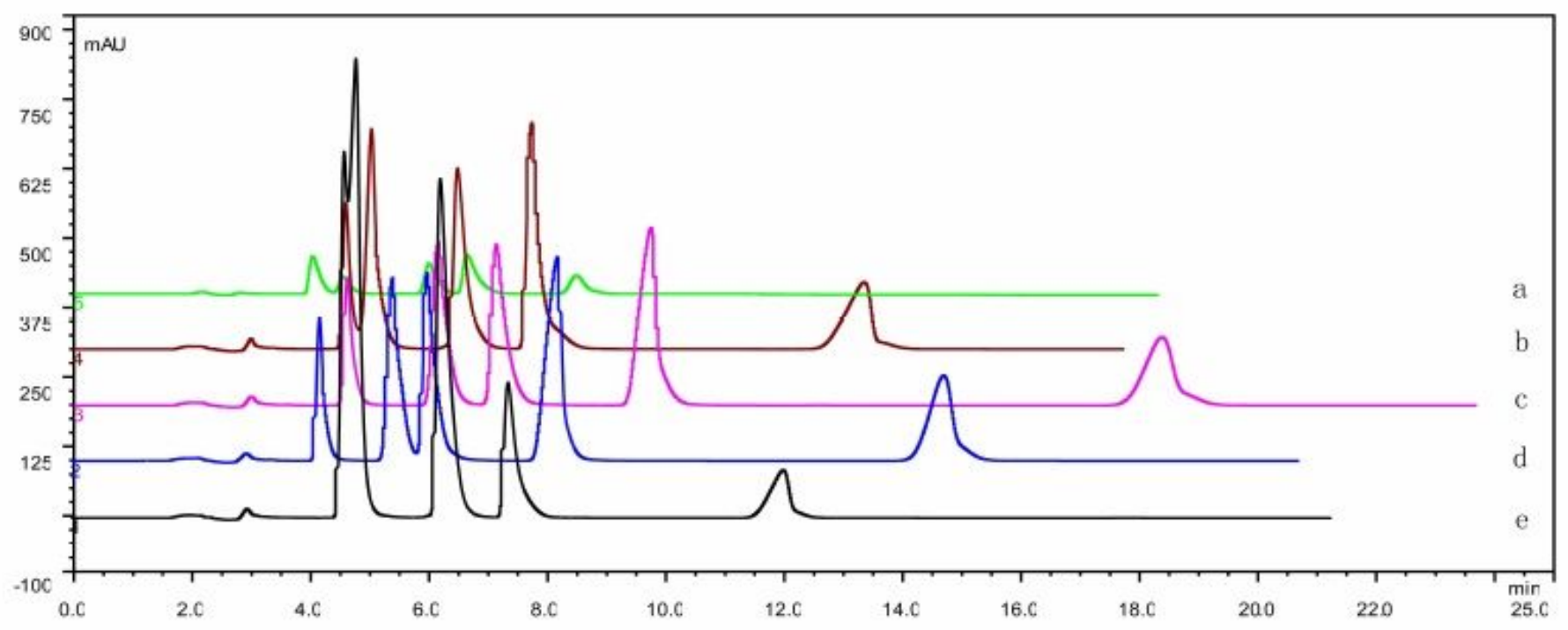

Figure 2

A typical chromatogram of standard drug mixture samples. Chromatographic conditions were acetonitrile- $0.05 \mathrm{~mol} \cdot \mathrm{L}-1$ potassium dihydrogen phosphate $(36: 64, \mathrm{v} / \mathrm{v})$; the buffer $\mathrm{pH}$ was varied. a. $\mathrm{pH}$ 3.0; b. pH 3.5; c. pH 4.0; d. pH 4.5; d. pH 5.0.

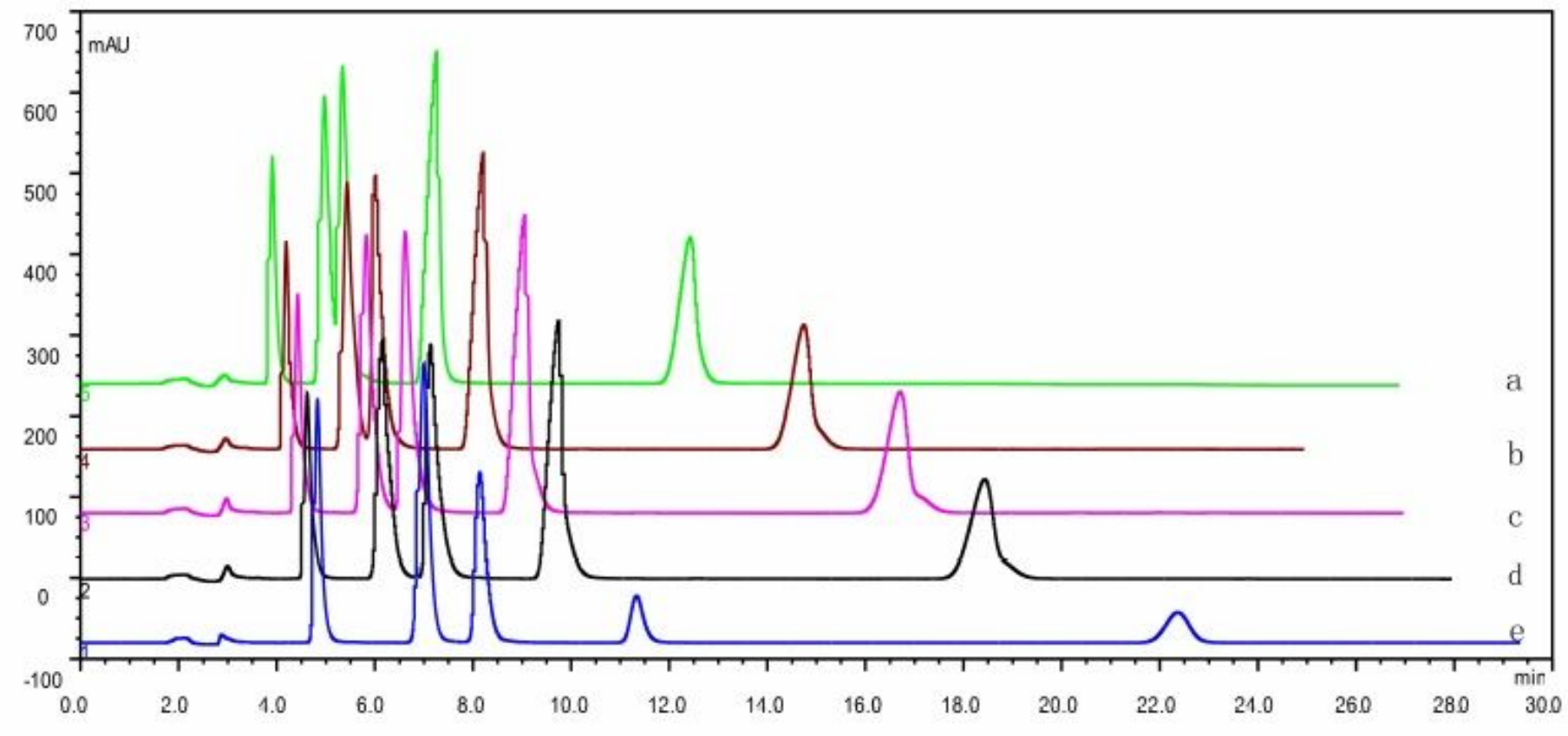

Figure 3

A typical chromatogram of standard drug mixture samples. Chromatographic conditions were acetonitrile- $0.05 \mathrm{~mol} \cdot \mathrm{L}-1$ potassium dihydrogen phosphate (phosphoric acid to adjust $\mathrm{pH}$ to 4.0 ); the 
acetonitrile content was varied. a. acetonitrile content 30 ; b. acetonitrile content 34 ; c. acetonitrile content 36 ; d. acetonitrile content 38; e. acetonitrile content 40.

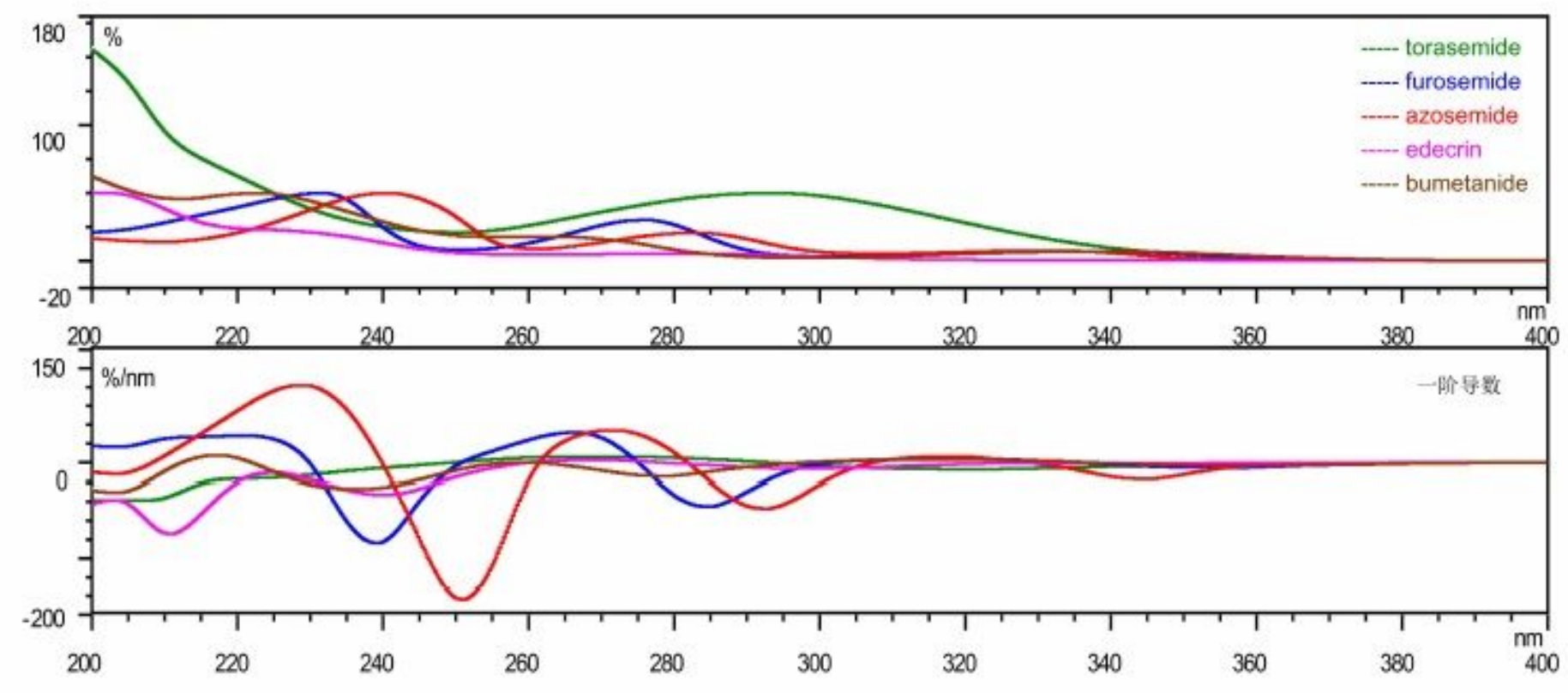

Figure 4

UV spectra and 1st UV spectra of furosemide, torasemide, azosemide, bumetanide and etacrynic acid. 